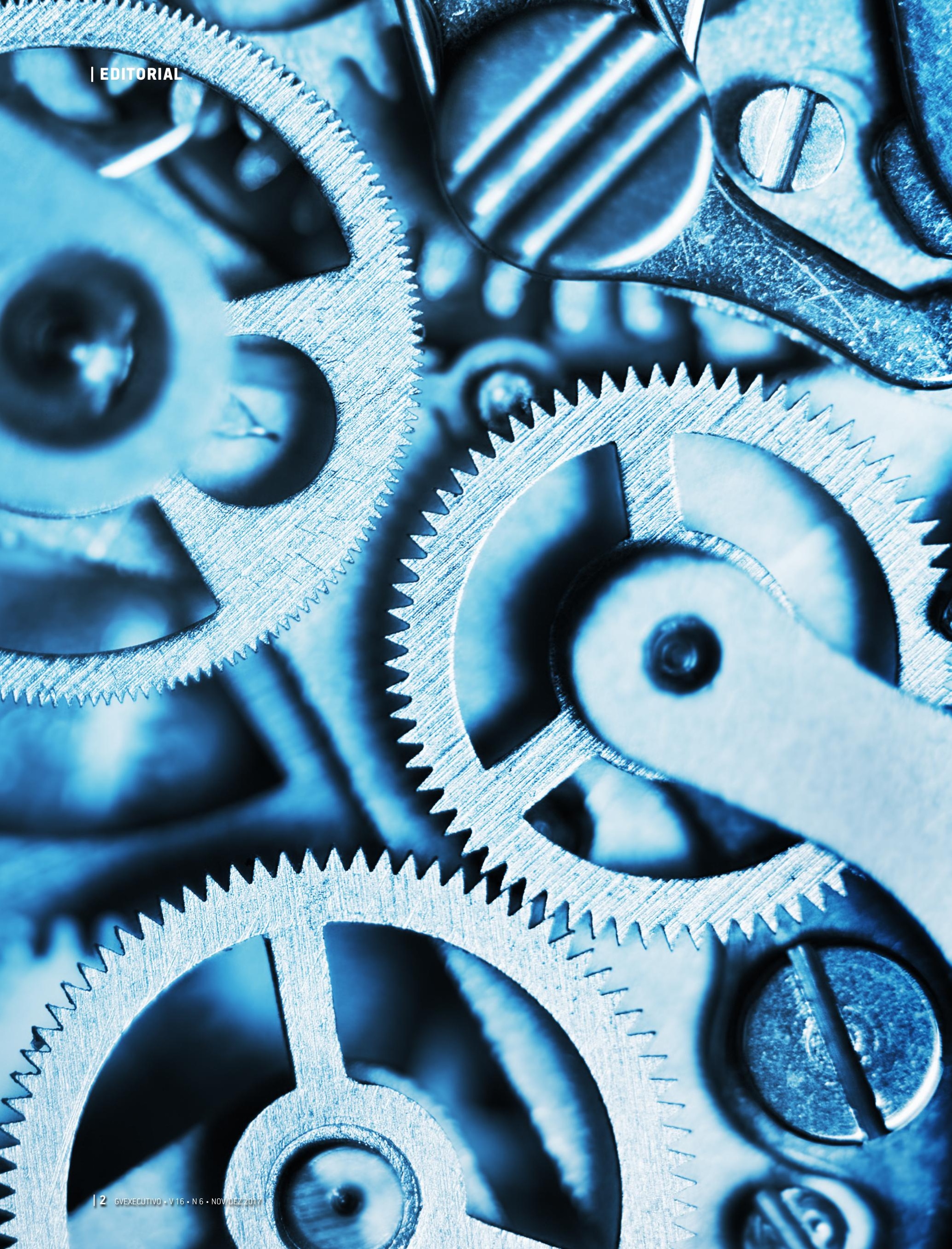




\section{NAS ENGRENAGENS DOS NEGÓCIOS}

A

GV-executivo fecha sua última edição deste ano com um caderno especial sobre supply chain, operações e logística. Não muitos anos atrás, essas áreas eram sinônimo de "chamar caminhão", como diz nossa entrevistada Eliane Rodrigues dos Santos, recém-promovida à diretora de logística da Basf para a América do Sul. Hoje, elas têm relevância estratégica e abrangem uma multiplicidade de questões essenciais para os negócios, como veremos nos artigos a seguir.

Cristiane Biazzin discute como as competências exigidas nesses campos são mais complexas atualmente. Em tempos em que as cadeias de suprimento se tornam globais, surgem novos desafios, tema de três artigos: Renata Peregrino de Brito defende a importância de se assegurar o respeito aos Direitos Humanos; Andrew Beheregarai Finger analisa as disputas de poder pela apropriação de valor agregado; e Susana Carla Farias Pereira e Luís Henrique Pereira revelam como lidar com os riscos maiores de ruptura nas empresas conectadas mundialmente.

Não há dúvidas entre os gestores das áreas de que novas ferramentas que vêm surgindo, por exemplo, para um processo de planejamento integrado, estão melhorando a gestão das operações. No entanto, questiona Marcelo Scarcelli, por que as empresas falham tanto em sua implantação? Conflitos de interesse impedem que sejam bem-sucedidas, argumenta.

No artigo de Priscila Laczynski de Souza Miguel e Paulo Fernandes, vemos que as vendas on-line aumentaram significativamente a oferta de produtos e sua redução de custo, mas é preciso investir em novos sistemas de logística. Na questão da exportação, demonstram Alexandre Pignanelli, Juliana Bonomi Santos e Dafne Oliveira Carlos de Morais, o baixo know-how é o que impede o avanço das pequenas, médias ou grandes empresas. Fechando esse caderno especial, o artigo de Fabio Campos Tescari e Eduardo Antonio Scalese Junior mostra que o customer service precisa conectar a área comercial à cadeia produtiva para proporcionar atendimento integral e flexível.

Nesta edição, contamos ainda com a colaboração de Claude Machline, professor emérito da FGV EAESP, que faz um tributo aos professores fundadores da EAESP. E nós fazemos aqui um tributo ao professor Claude Machline, que fundou a área de operações e logística no Brasil. Obrigada, professor Machline. Seus ensinamentos foram profícuos e geraram tanto conhecimento quanto melhores práticas em supply chain, logística e operações.

Completam esta edição as colunas: Um bom negócio?, por Samy Dana, em Fora da Caixa; E depois de 2018?, por Paulo Sandroni, em Economia e Prepare-se para o futuro do trabalho, por Sofia Esteves, em Projeto de Vida.

Neste último número, aproveitamos para agradecer a todos os autores, que abraçaram o novo projeto da $G V$-executivo e auxiliaram em sua realização. Aos membros dos cursos do Mestrado Profissional em Gestão para a Competitividade (MPGC), pelo apoio no conteúdo editorial, ajudando a consolidar a periodicidade bimestral da publicação. Aos patrocinadores que contribuíram conosco em 2017, PricewaterhouseCoopers (PwC), MPGC, Centro de Excelência em Varejo (GVcev) e Curso de Especialização em Administração Hospitalar e de Sistemas de Saúde (CEAHS), por acreditarem no propósito da $G V$-executivo de produzir e disseminar o melhor conhecimento em Administração, contribuindo para o crescimento da área. À toda a equipe RAE-Publicações, pelo esforço e comprometimento na produção da revista. E, por fim, aos leitores, a quem dedicamos nosso trabalho diariamente. Esperamos que continuem conosco no próximo ano.

Com esperança, feliz 2018!

Maria José Tonelli - Editora chefe

Adriana Wilner - Editora adjunta 